Olga Maciejewska

Uniwersytet Jagielloński
Etyka pracy socjalnej w filozofii spotkania i dialogu, red. M. Duda, I. Rybka, H. Kaszyński, Kraków 2017, s. 99-115 (Praca Socjalna w Teorii i Działaniu, 4).

DOI: http://dx.doi.org/10.15633/9788374386425.08

\title{
Znaczenie doświadczania wartości w edukacji studentów pracy socjalnej
}

\author{
The importance of the values experiencing \\ in the education of social work students
}

\begin{abstract}
Abstrakt: Celem tekstu jest podjęcie refleksji nad problematyką miejsca i znaczenia doświadczania wartości w edukacji studentów kierunków społecznych. Szczególna uwaga poświęcona zostanie pracy socjalnej, ujmowanej w kategoriach profesji. Podejmuję próbę przywołania wybranych metod akademickiego kształcenia, których wykorzystanie pozwala w moim rozumieniu osiągnąć pożądane efekty, wśród których wyróżnić należy przede wszystkim dążenie do refleksyjnego i krytycznego (samo)rozwoju młodych ludzi. Ważną rolę w tym procesie odgrywa doświadczenie duchowe rozumiane jako dalece wykraczające poza znaczenie wyłącznie religijne a nawet całkowicie $z$ religią niezwiązane. Doświadczenie duchowe obejmuje trzy kluczowe aspekty: poznawczy, wolitywny, emocjonalny - wyłącznie zaangażowanie „pełnią siebie” daje zrozumienie
\end{abstract}

Abstract: The aim of the text is to take the reflection on the issues of the place and the importance of the values experiencing in the education of students. Particular attention will be paid to the education of social work students. This field is understood today as a profession. I try to present the chosen methods of academic learning, which using allows - in my understanding - to achieve the desired effects. Above all the striving for reflective and critical (self)development of young people should be distinguished. An important role in this process plays a spiritual experience, understood as the phenomenon far beyond the purely religious significance - and even completely unrelated to religion. The spiritual experience includes three key aspects: cognitive, volitional, emotional. It means, that only the full engagement of phe- 
zjawisk trudnych, pojęć niejednoznacznych, kwestii dotykających i bolesnych. Duchowe doświadczenie rozumiem jako przeżycie na wskroś aksjologiczne. Konfrontowanie studentów $\mathrm{z}$ wartościami służy w moim rozumieniu kształtowaniu postaw i przekonań studentów. Doświadczanie wartości okazuje się być kategorią, nad którą także praca socjalna jako profesja ukierunkowana na kontakt i relacje, musi podjąć refleksję.

Słowa kluczowe: praca socjalna, doświadczenie duchowe, wartości, pedagogika szkoły wyższej, filozofia spotkania. nomena, ambiguous concepts, affecting and painful issues. The spiritual experience, as I understand, means the fully Axiological experience. Confrontation with the values can shape the attitudes and beliefs of students. The experiencing of the value turns out to be an category, above which the social work as a profession focused on contact and relationships, has to reflect.

Keywords: social work, spiritual experience, values, pedagogy of higher education, philosophy of the meeting.

Refleksję na temat problematyki miejsca i znaczenia doświadczania wartości w edukacji studentów kierunków społecznych - w tym w sposób szczególny studentów pracy socjalnej ujmowanej w kategoriach profesji - rozpocząć należy od przybliżenia znaczenia samej pracy socjalnej. Początków teorii polskiej doszukiwać się można w XIX wieku, „kiedy to potrzeba szeroko rozumianej oświaty ludu stawała się fundamentem programów społecznych" ${ }^{1}$. Twórczyni pedagogiki społecznej w Polsce Helena Radlińska określa pracę socjalną mianem „wydobywania i pomnażania sił ludzkich, [polega na] ich usprawnianiu i organizacji wspólnego działania dla dobra ludzi”2. Radlińska stworzyła teoretyczne podstawy pedagogiki społecznej na fundamencie swej praktycznej działalności, co miało niebagatelne znaczenie dla jej dalszej naukowej i zawodowej aktywności. Poszerzanie zakresu podejmowanych społecznych działań szło więc $\mathrm{w}$ parze z rozwojem teoretycznego zaplecza, co zaowocowało wyodrębnieniem w jej ramach trzech ważnych działów: teorii oświaty pozaszkolnej, teorii opieki

$1 \quad$ M. Brenk, Praca socjalna w pedagogice społecznej Heleny Radlińskiej, w: Ad novum fructum. Z okazji jubileuszu poznańskich historyków wychowania, red. W. Jamrożek, K. Ratajczak, D. Żołądź-Strzelczyk, s. 85, www.academia.edu/9099382/Praca_socjalna_w_pedagogice_spo\%C5\%82ecznej_Heleny_Radli\%C5\%84skiej (20.01.2017).

2 H. Radlińska, Szkoła pracy społecznej w Polsce, 1928, za: B. Szatur-Jaworska, Teoretyczne podstawy pracy socjalnej, w: Pedagogika Społeczna, red. T. Pilch, I. Lepalczyk, Kraków 1995, s. 106. 
i pomocy społecznej, historii pracy oświatowej i społecznej3․ Świadoma coraz bardziej dynamicznych przekształceń zachodzących w obszarze życia społecznego i kulturalnego, postulowała Radlińska rozszerzenie zakresu zainteresowania pedagogiki społecznej oraz wypracowanie wspólnej teorii wszelkiej pracy społecznej. Co istotne, pojmowała ową pracę społeczną jako działania wychowawcze ${ }^{4}$, co dziś rozpatrywać należy także w kategoriach szeroko rozumianej nowoczesnej pracy socjalnej. Sama Autorka widziała zaś pracę socjalną jako dziedzinę zajmującą się „świadomą działalnością wychowawczą, pomagającą przekształcać środowisko siłami jego mieszkańców, wykorzystując metody wypracowane w ramach refleksji teoretycznej tej nauki"s.

Zgodnie z zapisami obowiązującej na gruncie polskim ustawy o pomocy społecznej z dnia 12 marca 2004 roku praca socjalna „świadczona jest na rzecz poprawy funkcjonowania osób i rodzin w ich środowisku społecznym [...] wykorzystuje się właściwe tej działalności metody i techniki, stosowane z poszanowaniem godności osoby i jej prawa do samostanowienia [...] świadczona jest osobom i rodzinom bez względu na posiadany dochód"6. Przywołany zapis odnosi się do najważniejszych aspektów zawodowego funkcjonowania profesjonalistów, celów i specyfiki podejmowanych przez nich działań, narzędzi i technik realizacji zamierzeń, w końcu odbiorów świadczeń i usług. Celniejszym dla zrozumienia istoty nowoczesnej pracy socjalnej wydaje się jednak przywołanie międzynarodowej jej definicji przyjętej przez Zgromadzenie Ogólne Międzynarodowej Federacji Pracowników Socjalnych. Praca socjalna to „zawód, który promuje społeczne zmiany, rozwiązywanie problemów we wzajemnych ludzkich relacjach oraz wzmocnienie i wyzwolenie ludzi dla osiągnięcia przez nich dobrostanu [...] praca socjalna ingeruje dokładnie tam, gdzie dochodzi do wzajemnego oddziaływania ludzi z ich środowiskiem. Zasady praw człowieka i społecznej sprawiedliwości są fundamentalne dla pracy socjalnej"”. Chwila refleksji nad przytoczonymi słowami skłania do zastanowienia się nad zakresem obowiązków i powinności spoczywających na barkach tych, którzy decydują się uprawiać pracę socjalną. Po wtóre koniecznym jest uświadomienie sobie, w jak wiele kompetencji - niejednokrotnie bardzo od siebie odległych i niejedno-

\footnotetext{
3 A. Kamiński, Zakres i podstawowe pojęcia pedagogiki społecznej Heleny Radlińskiej, w: H. Radlińska, Pedagogika społeczna, Wrocław 1961, s. XX.

4 M. Brenk., Praca socjalna w pedagogice społecznej Heleny Radlińskiej, w: Ad novum fructum..., dz. cyt., s. 85.

H. Radlińska, Pedagogika społeczna..., dz. cyt., s. 21.

6 Ustawa o pomocy społecznej z 12 marca 2004 r., Dz. U. z 2004 r. Nr 64, poz. 593, art. 45.

7 Międzynarodowa definicja pracy socjalnej przyjęta przez Zgromadzenie Ogólne Międzynarodowej Federacji Pracowników Socjalnych w Montrealu w lipcu 2000 r., w: Instytut Rozwoju Służb Społecznych, http://wpis.irss.pl/definicja-pracy-socjalnej (28.01.2017).
} 
znacznie powiązanych - wyposażeni być muszą pracownicy socjalni. Na szkołach wyższych kształcących na kierunku praca socjalna oraz instytucjach przygotowujących do uprawiania zawodu pracownika służb społecznych ${ }^{8}$ spoczywa dziś ogromna odpowiedzialność związana z powinnością wyposażenia adeptów profesji w wiedzę, umiejętności i kompetencje uprawniające do uprawiania zawodu w sposób nie tylko rzetelny i zgodny z obowiązującymi normami, ale przede wszystkim twórczy, oparty na niepisanej regule ukierunkowania na Drugiego Człowieka i jego historię.

Temat podjęty w niniejszym tekście zobowiązuje do zastanowienia się nad rzeczywistą najgłębszą istotą pracy socjalnej. Jest nią miłość - rozumiana jednakowoż nie w kategoriach silnej kompilacji, opartej w dużej mierze na pożądaniu, emocjach i uczuciach łączących dwoje ludzi na pewnym etapie ich życia. Miłość, w rozumieniu, jakie przywołuję, staje się zasadą porządkującą życie człowieka - w odniesieniu do siebie samego, relacji, jakie buduje, otoczenia społeczno-kulturowego. Jeśli tak, to pracę socjalną rozpatrywać by należało jako swoistą odpowiedź na wołanie Drugiego. Tego, który sam nie może lub nie potrafi poradzić sobie z sytuacją, w jakiej się znalazł - a który zaufał. Człowiek zdolny do tak głębokiej wrażliwej miłości, by być pracownikiem socjalnym, odczuwał będzie innych jako Osoby - byty w pełni odrębne, ale współdzielące pewne doświadczenia. Właśnie w przestrzeni podzielanych przeżyć rozgrywa się w głównej mierze każda relacja.

Zaryzykuję stwierdzenie, że istnieją zagadnienia, których na gruncie jednej wyłącznie nauki czy dyscypliny nie sposób przedstawić i wnikliwie wyjaśnić, co wynika z ich złożoności, emocjonalnego i aksjologicznego wymiaru, kulturowych i społecznych uwarunkowań ich kształtowania się i rozwoju. W związku z tym nie sposób również nauczać o nich w sposób „tradycyjny”. Bez wątpienia takim właśnie zagadnieniem jest praca socjalna wymykająca się jednoznacznym definicjom, ale i obarczona koniecznością zachowania pewnej elastyczności i wrażliwości na zmieniające się czasy. Pojawia się zatem pytanie, w jaki sposób i jakimi środkami budować kulturę pomagania? Pytanie to towarzyszyć musi adeptom profesji i kształcącym ich ekspertom podczas całego procesu edukacji.

Zawód pracownika socjalnego postrzegany jest jako zawód społecznego zaufania i szczególnej odpowiedzialności. Pełniony być powinien zatem przez osoby w najwyższym stopniu do niego przygotowane. Nowe zadania wymagają od profesjonalistów nie tylko nowych kompetencji, ale także umiejętności, które

8 W myśl ustawy o pomocy społecznej osoba chcąca pracować zawodowo w roli pracownika socjalnego winna spełnić następujące kryteria: posiadać dyplom ukończenia kolegium pracowników służb społecznych, ukończyć studia wyższe na kierunku praca socjalna, za: Ustawa o pomocy społecznej z 12 marca 2004 r., Dz. U. z 2004 r. Nr 64, poz. 593. 
wykształcone być mogą wyłącznie wskutek ćwiczeń praktycznych i bezpośredniego kontaktu z osobami doświadczającymi określonych trudności. Pracownicy socjalni, jako osoby niejednokrotnie „pierwszego kontaktu”, naznaczeni zostają odpowiedzialnością w sposób szczególny. Spojrzenie z tej perspektywy uzmysławia, do jak wielu ról musi być przygotowany współczesny pracownik socjalny, by jego działania stanowiły efektywną odpowiedź na rzeczywiste potrzeby i oczekiwania społeczne. Poza dostarczaniem rozległej wiedzy, pozwalającej dostrzegać i definiować problemy członków danej społeczności w szerokim kontekście ich uwarunkowań, koniecznym jest wyposażenie pracowników socjalnych w umiejętności doboru adekwatnych metod postępowania w konkretnych okolicznościach i przypadkach, dokonywania na bieżąco analizy zależności między szeregiem czynników współtworzących daną sytuację, właściwego definiowania ról swoich oraz swych klientów i współpracowników. Nie mniej ważne jest zwrócenie uwagi na umiejętności interpersonalne. W procesie edukacji koniecznym jest podjęcie działań służących kształtowaniu odpowiednich postaw osób zawodowo zajmujących się niesieniem pomocy i wsparcia potrzebującym.

Nie sposób nie pochylić się w tym miejscu nad problematyką duchowości. Podjęte rozważania osnute będą wokół problematyki znaczenia doświadczenia duchowego w procesie edukacji studentów pracy socjalnej. Doświadczenie owo - jak zostanie ukazane w dalszej części - rozumiem jako dalece wykraczające poza znaczenie wyłącznie religijne, a nawet całkowicie z religią niezwiązane.

Edukacja staje się w XXI wieku jednym z najbardziej istotnych obszarów życia, wobec którego nieustannie niemal formułowane są coraz to nowe, różnorodne oczekiwania i postulaty koniecznych zmian. Najogólniej rzecz ujmując, szkolnictwo wyższe odgrywa szczególną rolę jako „element systemu tworzenia i wdrażania wiedzy, zwłaszcza w kontekście kształtowania społeczeństwa wiedzy (gospodarki opartej na wiedzy)"'. Co więcej, akademicka edukacja ujmowana jest (i być powinna) jako fundamentalny element misji szkoły wyższej. Jak pisze Zbyszko Melosik, przestaje ona być „świątynią mądrości, majestatycznym symbolem Prawdy i Wiedzy"10, staje się natomiast jedną z instytucji społecznych a nawet - w sytuacji komercjalizacji uniwersytetów - ekonomicznych. Bez wątpienia zadbać należy zatem przede wszystkim o właściwą jakość kształcenia ${ }^{11}$. Wydaje się, że jednym z kluczowych aspektów - niepodejmowanych jednak w należy-

97 lutego 2011 r. odbyła się debata zatytułowana Uczelnie tworza społeczeństwo wiedzy, podczas której Minister Nauki i Szkolnictwa Wyższego prof. Barbara Kudrycka stwierdziła: „Nauka i szkolnictwo wyższe stają się najważniejszym przemysłem XXI wieku. Przemysłem, który nie tylko zatrudnia wielu pracowników, ale ma też wpływ na jakość kadr decydujacych o rozwoju państwa".

10 Z. Melosik, Uniwersytet i społeczeństwo, Kraków 2009.

11 K. Denek, Ku uniwersytetowi przyszłości, „Nowa Szkoła” 2010, nr 9 (687), s. 5. 
tym zakresie - debaty toczącej się wokół potrzeby reformy edukacji, jest postulat zmian w zakresie stosowanych metod kształcenia. W tym miejscu zasadnym jest postawienie pytania, $w$ jaki sposób i w jakim nurcie przebiegać powinna owa reforma? Jakie właściwie metody pracy ze studentami uznać można za właściwe dla realizacji celu, którym jest kształcenie młodego pokolenia z jednej strony, ale i sprostanie wymogom współczesności z drugiej. Zagadnienie nie jest proste i niemożliwe jest udzielenie jednej właściwej odpowiedzi. W tekście niniejszym podejmuję próbę przywołania wybranych metod akademickiego kształcenia, których wykorzystanie pozwala w moim rozumieniu osiągnąć pożądane efekty. Istotnym kontekstem dla prowadzonych rozważań jest, co istotne, specyfika uczenia się osób studiujących na kierunkach społecznych.

W procesie akademickiej edukacji formą wciąż dominującą są wykłady. Zajęcia konwersatoryjne prowadzone są natomiast $w$ tak licznych grupach, że nie stwarzają warunków do pozostawiania przestrzeni działania dla studentów i ich aktywizowania, pobudzania młodych ludzi do samodzielnego myślenia i podejmowania działań. $\mathrm{W}$ dużej mierze samodzielne konstruowanie wiedzy i kształtowanie kompetencji - w tym szczególnie tzw. kompetencji miękkich (osobistych i interpersonalnych) ${ }^{12}$ - staje się wyzwaniem dla samych studiujących. Dobór metod edukacji akademickiej oparty być powinien - obok kwestii oczywistych, jakimi są cele i zadania, treści przewidziane do realizacji, stopień przygotowania nauczyciela akademickiego do prowadzenia zajęć dydaktycznych - na specyficznych cechach rozwojowych studentów, ich możliwościach intelektualnych i kompetencjach współżycia społecznego. Według koncepcji Erika Eriksona okres studiów przypada na dwa istotne etapy rozwojowe, a mianowicie koniec etapu dojrzewania i wejście w okres wczesnej dorosłości ${ }^{13}$, co jest o tyle istotne, że jest to moment przełomowy dla kształtowania się jednostki. Adolescencja uznawana jest za najtrudniejszy okres w życiu człowieka, bowiem jej głównym zadaniem rozwojowym jest zbudowanie własnej tożsamości. Tłem tego procesu jest podejmowanie kolejnych prób konfrontacji z sobą samym oraz z otaczającym dynamicznym światem, celem zaś zdefiniowanie samego siebie, jako indywiduum. W okresie wczesnej dorosłości natomiast kształtują się głębsze relacje z innymi. Co więcej, jest to okres najwyższej sprawności uczenia się ${ }^{14}$.

Nakreślona specyfika okresu studiów wymusza podjęcie trudu doboru metod nie tylko adekwatnych, ale i uwzględniających przemiany zachodzące w roz-

12 A. Szerląg, Oczekiwania wobec absolwenta szkoły wyższej jako podmiotu edukacji, w: A. Szerląg, Kompetencje absolwentów szkół wyższych na miarę naszych czasów. Wybrane ujęcia, Wrocław 2009, s. 36.

13 E. Erikson, Dzieciństwo i społeczeństwo, Poznań 2000.

14 E. Erikson, Dzieciństwo i społeczeństwo..., dz. cyt. 
woju młodego człowieka. Edukacja na poziomie wyższym opierać się powinna na modelu zorientowanym na studenta, który charakteryzuje się dominacją uczenia się nad nauczaniem. Student staje się samodzielnym w dużej mierze podmiotem procesu, odpowiedzialnym za jego przebieg, jakość i efekty. Nie będzie zatem nadużyciem stwierdzenie ogromnego znaczenia posiadanego doświadczenia edukacyjnego i życiowego. Odpowiedzią na zarysowane potrzeby wydają się być warsztatowe i projektowe formy zajęć umożliwiające młodym ludziom grupowe doświadczanie zdobywania wiedzy i realizacji praktycznych działań w oparciu o wykorzystanie modeli doświadczania wartości.

We współczesnej pedagogice odnaleźć można dwa odmienne podejścia do problematyki człowieka. Pierwsze ,jest owocem transformacji cywilizacyjnej, zrywa z kolektywizmem wychowawczym [...] i deklaruje - przynajmniej nominalnie - zwrot ku personalizmowi"15. Głosi ono mianowicie, że każdy człowiek jest kimś absolutnie wyjątkowym, a wyjątkowość owa manifestuje się w jego indywidualnej podmiotowości, niepodważalnej godności, wolności. Drugie stanowisko z kolei, deklarując potrzebę odejścia od pedagogiki kolektywistycznej, traktuje personalizm w kategoriach ideologii stricte religijnej. Wiąże go bowiem $\mathrm{z}$,partykularną pedagogiką chrześcijańską" ${ }^{16}$. Na miejscu wykluczonych uprzednio kolektywizmu i personalizmu widzi liberalny model wychowania - tzw. indywidualizm pedagogiczny. Wydaje się, że taki postulat nie znajduje i znaleźć nie może uzasadnienia i miejsca we współczesnych, szeroko pojmowanych, oddziaływaniach edukacyjnych i wychowawczych. Silnie redukuje bowiem rzeczywistość wychowawczą, odzierając ją z bogatego aksjologicznego wymiaru i społeczno-kulturowych odniesień, tak istotnych dla rozwoju jednostki.

Bez wątpienia wartościowym dla podjętych tu rozważań jest zatrzymanie się na moment nad nurtem personalistycznym. Stanowi on w moim rozumieniu ważną odpowiedź na realia współczesnego świata płynnej nowoczesności. Przypuszczać można, że personalistyczny nurt myślenia pojawił się jako swoisty „protest przeciw wszelkim próbom «urzeczowienia» człowieka” ${ }^{17}$. Wskazuje bowiem jednoznacznie na najwyższą i wyjątkową pozycję osoby ludzkiej wśród ogółu bytów, przypominając równocześnie, że zawsze stanowić ma ona cel życia społecznego. Ignacy Dec zaznacza w swej monografii, iż istnieje „wiele nurtów, szkół, ruchów społecznych, które chętnie określają siebie jako personalistyczne"18. Sytuację taką postrzegać można w kategoriach pewnego zagrożenia dla

15 I. Dec, Personalizm, w: Powszechna Encyklopedia Filozofii, red. A. Maryniarczyk, t. 8, Lublin 2007, s. 122.

16 I. Dec, Personalizm, w: Powszechna Encyklopedia..., dz. cyt.

17 I. Dec, Personalizm, w: Powszechna Encyklopedia..., dz. cyt.

18 I. Dec, Personalizm czy personalizmy?, w: Osoba i realizm w filozofii. Zadania Współczesnej Metafizyki, red. A. Maryniarczyk, K. Stępień, Lublin 2002, s. 47; zob. także: 
samej idei. Ponadto stwarza ona trudności w pełnym zrozumieniu i dokonaniu krytycznej analizy personalizmu jako szerszego pojęcia. Dec wyodrębnił trzy typy (czy odmiany) personalizmów. Pokrótce je omówię, przywołując kluczowe ich elementy.

1. Personalizm horyzontalny (ateistyczny)

Człowiek ujmowany jest w nim jedynie jako część materialnego świata. Duchowy wymiar życia zostaje całkowicie pomięty. A to on stanowił pierwotnie podstawę wypracowania koncepcji człowieka jako osoby. Odmianę tę charakteryzuje wyraźny antropologiczny redukcjonizm. Sama idea człowieka uzależniona jest od pewnej struktury nadrzędnej - przykładowo popędów czy państwa, „czego konsekwencją jest zagubienie, a nawet degradacja ontologiczna człowieka"19.

2. Wertykalny (teistyczny) - pozatomistyczny

Obejmują podgrupy, które Dec ujął w sposób następujący ${ }^{20}$ :

- personalizm moralno-społeczny (E. Mounier);

- personalizm fenomenologiczno-aksjologiczny (M. Scheler, R. Ingarden);

- personalizm egzystencjalistyczno-dialogiczny (K. Jaspers, G. Marcel);

- personalizm ewolucyjno-kosmiczny (P. Teilhard de Chardin).

Silną stroną każdego z powyżej wymienionych stanowisk jest fakt, iż uwzględniają one element duchowy w strukturze osobowości człowieka oraz jego transcendencję wobec świata natury. Problematyczne okazuje się jednak wyraźne wskazanie czynników odróżniających człowieka od innych bytów, „a co tym samym stanowi o jego prawdziwej godności oraz wyjątkowości”21. Personalizmy te nie dostrzegają zatem metafizycznego aspektu życia ludzkiego.

3. Klasyczny - tomistyczny o orientacji metafizycznej

Nawiązuje do klasycznej antropologii Greków, wzbogaconej jednakowoż przez chrześcijańskie Objawienie oraz filozoficzno-teologiczną myśl średniowiecza (m.in. Tomasz z Akwinu). W człowieku widzi ów personalizm jednostkową rozumną substancję. Zdaniem Deca, „by ująć człowieka w tym, kim on rzeczywiście jest, należy sięgnąć do personalizmu teistycznego-tomistycznego, wyrasta on bowiem z realizmu poznawczego"22.

W. Chudy, Pedagogia godności. Elementy etyki pedagogicznej, red. A. Szudra, Lublin 2009, s. $24-25$.

19 Jako przedstawicieli tego nurtu personalizmu Ignacy Dec wymienia także m.in. L. Feuerbacha, K. Marksa, F. Engelsa, F. Nietschego, Z. Freuda, B. Russella, J. P. Sartre’a, T. Kotarbińskiego.

$20 \quad$ I. Dec, Personalizm, w: Powszechna Encyklopedia..., dz. cyt., s. 124.

21 I. Dec, Personalizm, w: Powszechna Encyklopedia..., dz. cyt.

22 Zob. I. Dec, Personalizm czy personalizmy?, w: Osoba i realizm..., dz. cyt., s. 57-58. 
To krótkie przedstawienie charakterystyki bogatego nurtu personalistycznego służyć miało uwypukleniu jego znaczenia jako możliwego fundamentu wszelkich oddziaływań socjalnych - ukierunkowanych na relację z drugim człowiekiem i urzeczywistnienie wartości we wspólnocie. Jednym z fundamentalnych czynników organizujących aktywność osób dążących do zmiany systemu kształcenia pracowników socjalnych zdaje się być zrekonstruowanie oblicza samej pracy socjalnej. Dokonać się to może poprzez zmianę perspektywy na tę opartą o nurt personalistyczny. Już na etapie studiów wyższych podjęty być musi trud przejścia ku relacyjnej pracy socjalnej. Drogą ku temu zdaje się być wykorzystanie metod kształcenia opartych o doświadczanie wartości - ich poznawanie, nazywanie, eksponowanie i współtworzenie - w obliczu Drugiego.

„Inny” jako kategoria filozoficzna wydobyty został niejako z przywiązania myślicieli do dwóch podstawowych paradygmatów: arystotelesowskiego - przedmiotowego oraz kartezjańskiego - podmiotowego. Filozofowie dialogu zaś zajęli się w sposób szczególny nową kategorią, jaką stało się „Ty”, przyczyniając się do powstania trzeciego paradygmatu - mianowicie obok ,jest" $i$,jestem" pojawiło się ,jesteś" ${ }^{\prime 2}$, co zmieniło optykę patrzenia na relacje międzyludzkie i siłę dialogu. „Ty” jest jednocześnie wezwaniem do odpowiedzialności. Przywołanie w tym kontekście postaci Karola Wojtyły kieruje uwagę na jego autorską adekwatną antropologię $e^{24}$ wskazującą, iż w strukturze człowieka jest „immanentnie konstytutywna gotowość do bycia dla kogoś drugiego, będąca cechą uwarunkowaną ontologicznie". Człowiek jest bytem potencjalnym i niesamowystarczalnym, przygodnym - dlatego też charakterystycznym dla niego jest bycie z natury bytem otwartym na drugą osobę. Od strony negatywnej potwierdza to doświadczenie samotności. Uczestnictwo ${ }^{25}$ jest dynamiczną, wewnętrzną właściwością osoby. Wojtyła przywołuje dwa podstawowe jego znaczenia ${ }^{26}$. Pierwsze jest związane z uczestnictwem w człowieczeństwie drugiego poprzez pozostawanie z nim w żywej relacji. Drugie znaczenie "polega na spełnianiu siebie jako osoby we współżyciu i współdziałaniu z innymi na rzecz dobra wspólnego" ${ }^{27}$. W tym rozumieniu uczestnictwo realizuje się poprzez zdolność bycia darem bezinte-

23 A. Węgrzecki, Wokół filozofii spotkania, Myśl filozoficzna, Kraków 2014.

24 Zob.: M. Grabowski, W strone antropologii adekwatnej, w: O antropologii Jana Pawła II, red. M. Grabowski, Toruń 2004, s. 15-67.

25 Zob.: M. Sztaba, Kategoria uczestnictwa $w$ odniesieniu do rodziny w świetle myśli Karola Wojtyły - bł. Jana Pawła II, „Nauki o edukacji” 2011, nr 6, s. 39-52.

26 Zob.: K. Wojtyła, Uczestnictwo czy alienacja?, w: K. Wojtyła, Osoba i czyn, Kraków 1985, s. $447-461$.

$27 \quad$ M. Sztaba, Dobro wspólne jako podstawowa wartość społeczna i zasada życia społecznego. Refleksje pedagoga społecznego, w: Centralne kategorie współczesnej i historycznej pedagogiki, red. S. Sztobryn, K. Kamiński, Łódź 2016 (Rzeczywistość edukacyjna, 3). 
resownym dla drugiego, dla innych. Tego właśnie uczyć się powinni studenci pracy socjalnej! Inności nie sposób odkryć inaczej, niż napotykając ją - poprzez spotkanie jej i doświadczanie następujące w relacji. W niej bowiem dochodzi do odsłonięcia tożsamości „Ja" i „Ty”, ale i tożsamości kształtujących się na nowo, czerpiąc z drugiego i z samego spotkania. Filozofowie dialogu jednoznacznie podkreślają, że inny i jego „inność” wydarza się i urzeczywistnia właśnie w spotkaniu - i tylko w nim. Poprzez nie i w nim następuje bowiem „zderzenie" inności spotykających się osób, które od tej chwili stają w obliczu innego. Każde takie spotkanie jest wydarzeniem niepowtarzalnym, wyjątkowym, rozwojowym. Siebie samego poznać można bowiem wyłącznie poprzez innego - i w nim. Ważne dla realizacji nowoczesnej i profesjonalnej edukacji na kierunku praca socjalna jest założenie, że „człowiek przeżywa, a więc i doświadcza siebie samego poprzez moralność, która stanowi szczególną podstawę zrozumienia człowieczeństwa. Z drugiej zaś strony doświadczenia moralności - a w ślad za tym i jej zrozumienia - niepodobna oderwać od człowieka i człowieczeństwa [...]. Istota moralności oraz człowieczeństwa są związane z sobą nierozłącznie"28.

Zgodnie z zapisami ustawy Prawo o szkolnictwie wyższym „w swoich działaniach uczelnie kierują się zasadami wolności nauczania, wolności badań naukowych oraz wolności twórczości artystycznej”29, co w sposób bezpośredni wiąże się z faktem, że szkoła wyższa jest miejscem nie tylko kształcenia i edukowania młodych ludzi, ale także kształtowania ich charakteru i poczucia wolności. Student podejmować powinien aktywność ukierunkowaną na uczenie się poprzez działanie - już nie uczenie się dla przyszłego potencjalnego działania. Różnica wydaje się być całkowicie jasną i zrozumiałą. Przesunięcie uwagi z procesu nauczania na rzeczywistą aktywność, przy jednoczesnym odchodzeniu od sformalizowanych i jednoznacznie zdefiniowanych ścieżek postępowania (wobec) studentów, otwiera nowe możliwości. Podstawą realizacji zajęć ukierunkowanych na rozwój studentów i rozbudzenie ich wrażliwości na Drugiego i jego historię, stać się powinien model wspólnego badania wartości. Przyświeca mu idea wspólnego odkrywanie siebie i swojego sposobu postrzegania świata w procesie dojrzewania - „stawania się”. Konieczne jest przy tym odsłanianie swoich indywidualnych doświadczeń, przeżyć (także tych trudnych), dzielenie się z innymi swoimi emocjami - a wszystko to w bezpiecznej atmosferze niewielkiej grupy. Celem zajęć musi się stać stworzenie przestrzeni dla grupowego doświadczania

\footnotetext{
${ }_{28}$ K. Wojtyła, Problem doświadczenia w etyce, „Roczniki Filozoficzne KUL” 1969, nr 2, s. 19.

Ustawa Prawo o szkolnictwie wyższym z dnia 27 lipca 2005 r., Dz. U. Nr 164, poz. 1365, art.4, ust. 2.
} 
wartości. Jak zaznaczył Husserl, „nie ma poznania bez doświadczenia”. Słowa te stać się powinny pewnym credo przyświecającym działaniom akademickim.

Wartości w ludzkim życiu manifestować się mogą w sposób bezpośredni lub pośredni ${ }^{30}$ - poprzez określone medium. Druga z sytuacji wydaje się być szczególnie interesującą i stosowną dla działań realizowanych w procesie edukacji studentów kierunków społecznych. Owo medium to dzieło, to drugi człowiek, to historia opowiedziana lub odczytywana, bowiem „choć nie umiemy trafnie wyartykułować ich własnego imienia - nie zmienia to podstawowego faktu naszej egzystencji, że zawsze w głębi serca żyjemy wartościami i dla wartości” ${ }^{31}$. Antoni Siemianowski podkreśla, że zaprzestając dokonywania wartościowania świata i porzucając trud odnoszenia wartości do siebie i innych, jednostka przestaje być sobą w sposób autentyczny. Wartości bowiem są „rdzeniem naszej egzystencji i źródłem autentycznego i rozumnie uzasadnionego sensu $\dot{z} y c i a{ }^{32}$. Zniknięcie wartości z życia człowieka pozbawia go poczucia uporządkowania, co z kolei naraża go dodatkowo na utratę sensu. Poszukiwanie autentycznych prawd i doświadczanie wartości w wieku przełomu, (jakim bez wątpienia pozostaje okres studiów) służy podjęciu trudu przemiany siebie samego i zrozumienia tego, co otacza człowieka. Samo słowo - nawet najpiękniej wypowiedziane - nie ukaże znaczenia wydarzeń, nie odda głębi emocji wiążących się $\mathrm{z}$ relacją. Student powinien ich doświadczyć. Z relacji Viktora Frankla zawartej w książce Psycholog w obozie koncentracyjnym wynika, że „słusznie o wartościach mówimy, że są pierwotnymi danymi naszego egzystencjalnego doświadczenia [...]. Jako takie mogą więc być podstawą i źródłem rozumnie uzasadnionego poczucia sensu $\dot{z} y c^{\prime \prime}{ }^{\text {"3z }}$.

Pojęcie „duchowość” przywołuje na myśl w sposób niemal automatyczny problematykę religii. Istotnym jest, że doświadczenie duchowe nie jest jednak zarezerwowane dla sfery zjawisk związanych z religią czy praktykami określonego systemu religijnego. Wiara zdaje się być czymś zupełnie odrębnym. Paweł Sochy wyodrębnił dziedziny aktywności ludzkiej, które z całą pewnością nazwać można duchowością: świadomość i samoświadomość, mądrość, uczucia,

30 Oblicza doświadczenia aksjologicznego. Studia i rozprawy, red. P. Duchliński, G. Hołub, Kraków 2011 (Universum philosophiae).

31 A. Siemianowski, Wartości i sens życia z punktu widzenia ontologicznego, w: Wartości dla życia, red. K. Popielski, Lublin 2008.

32 A. Siemianowski, Wartości i sens życia z punktu widzenia ontologicznego, w: Wartości dla..., dz. cyt.

33 V. E. Frankl, Psycholog w obozie koncentracyjnym, za: A. Siemianowski, Wartości i sens życia z punktu widzenia ontologicznego, w: Wartości dla..., dz. cyt. 
wrażliwość, moralność, twórczość, religijność, wiara ${ }^{34}$. Ponadto doświadczenie duchowe obejmuje trzy kluczowe aspekty: poznawczy, wolitywny, emocjonalny. Dopiero zaangażowanie „pełnią siebie” daje zrozumienie zjawisk trudnych, pojęć niejednoznacznych, kwestii dotykających i bolesnych. Zgodnie z poglądami André Comte-Sponville’a doświadczenia duchowe, do których zaliczyć można wieczność, tajemnicę, pełnię, są obecne zarówno u osób wierzących, jak i ateistów - choć poczucie transcendencji tych ostatnich nie jest oparte na Bogu ${ }^{35}$.

Doświadczaniu wartości, które właśnie rozumiem jako doświadczenie na wskroś duchowe, sprzyja sięgnięcie po formy artystycznej ekspresji - literatura, sztuka, fotografia, film, teatr, instalacje multimedialne i performance. Na ich wykorzystaniu opierać się zatem powinien proces kształcenia adeptów profesji ukierunkowanych na udzielanie wsparcia i pomocy. Co więcej, doświadczenie duchowe zawsze zakotwiczone jest w naszych indywidualnych przeżyciach, uczuciach i emocjach, pragnieniach. W sferze intelektualnej zaś obejmuje myśl, ideę oraz wolę (podejmowanie decyzji). Fundamentem i pierwszym punktem odniesienia są wszelkie sytuacje o charakterze egzystencjalnym, które w większym lub mniejszym stopniu dotykają samej istoty człowieka ${ }^{36}$. Doświadczenie duchowe oparte na odnajdywaniu i odczytywaniu wartości wyraża znacznie więcej, niż mówi o nim jego zmysłowa strona - przez co uważane być może za nieuchwytne, nieobiektywne. Podjęcie dyskusji nad doświadczeniem tego typu zdaje się ogromnym wyzwaniem, przed jakim stoją studenci.

Pewna nieokreśloność znaczeń, na którą niewątpliwy wpływ ma postmodernistyczny dyskurs dominujący we współczesności, nie przyczynia się do zrozumienia niełatwych do interpretacji, tak złożonych i niejednoznacznych fenomenów. Jak napisał Zygmunt Bauman, „,nowoczesność [...], staje się nieuchwytna: odkrywamy nagle, $\dot{z} e$ pojęcie najeżone jest wieloznacznością, podczas gdy przedmiot, do jakiego odsyła, ma nieprzejrzyste jądro i zamazane kontury" ${ }^{37}$. Rozumienie społecznych i kulturowych zjawisk naznaczone zostało dużą dozą niepewności, co wynika także z pewnej chwiejności ustalonego porządku rzeczy, przyjętych norm postępowania, a w końcu niepewności samego istnienia wiedzy i wartości. Nastanie ponowoczesności sprawiło, że zjawiska o dotychczas jasnym statusie ontycznym, przeradzać się poczęły w coś zupełnie nieoczywistego. Bauman w Prawodawcach i tłumaczach pytał: „Czy obecny kryzys pewności jest

\footnotetext{
34 P. Sochy, Duchowy rozwój człowieka. Faza życia, osobowość, wiara, religijność, Kraków 2000

35 Zob. A. Comte-Sponville, Duchowość ateistyczna, tłum. E. Aduszkiewicz, Warszawa 2011, s. 5.

36 Oblicza doświadczenia aksjologicznego. Studia i rozprawy..., dz. cyt.

37 Z. Bauman, Wieloznaczność nowoczesna. Nowoczesność wieloznaczna, tłum. J. Bauman, Warszawa 1995, s. 14-15.
} 
rezultatem chwilowej utraty czujności? Czy to typowy okres przejściowy, który następuje po i przed kolejnymi zmianami form organizacji społecznej? A może jest pierwszym zwiastunem tego, co dopiero nastąpi?"38. Udzielenie odpowiedzi w sposób pewny i pozbawiony wątpliwości okazuje się niemal niemożliwym. Koniecznością jest zatem ciągłe poszukiwanie. Stan taki prowadzi do skutków, których nie sposób ocenić w tym miejscu i czasie. Cierpi na tym niewątpliwie duchowa sfera człowieka. Pewna aksjologiczna bezradność jawi się bowiem jako jeden z zasadniczych objawów współczesności, co rodzi realne zagrożenie w postaci uproszczeń. Dla pluralistycznej myśli nurtu postmodernistycznego doświadczanie wartości przez człowieka pozostaje problemem ciągle otwartym. Szczególnego znaczenia nabiera przy tym kwestia dehumanizujących przemian rzeczywistości złożonej w coraz większym stopniu z żyjących swoim własnym życiem indywidualności. Ginie potrzeba doświadczania zbiorowości. Czy zadaniem kształcenia na kierunku praca socjalna właśnie nie powinno być podjęcie działań na rzecz odbudowy owej potrzeby?

Doświadczenie duchowe rozumiem jako doświadczenie na wskroś aksjologiczne. Związane jest to $\mathrm{z}$ naturą samego człowieka, jako istoty aksjologicznej, od zarania borykającej się z kwestią wartości - ich poszukiwania, odkrywania i doświadczania, realizacji w codziennym życiu, rozpoznawania i definiowania. Człowiek doświadcza swej „aksjologiczności” ${ }^{39}$ nieustannie, co realizuje się poprzez spotkanie z drugim człowiekiem, światem zewnętrznym - ale także z samym sobą, jako osobą nieustannie (samo)rozwijającą się i dążącą ku wartościom. Spotkanie takie nigdy nie jest neutralne! Doświadczenie duchowe okazuje się zatem kategorią, nad którą także praca socjalna, jako profesja ukierunkowana na kontakt i relacje, musi podjąć refleksję. Doświadczanie wartości, rozumiane jako ściśle aksjologiczne, staje się źródłem, dostarcza inspiracji, intuicji, wskazań i pomysłów. Wartości poznaje człowiek poprzez bezpośrednie odczuwanie - emocjonalne zaangażowanie. Stają się one poznawczo dostępne dopiero przy współudziale uczuć, co jest warunkiem koniecznym! Takie źródłowe doświadczenie wartości określane jest mianem emocjonalnej percepcji wartości (emocjonalną intuicją wartości $)^{40}$.

Pojawić się może w tym miejscu pytanie, dlaczego doświadczenie duchowe tożsame jest z tym aksjologicznym? Za odpowiedź niech służy fakt, że zakłada ono transcendencje - przekraczanie siebie, kształtowanie i (re)konstruowanie tożsamości. Zdaniem Antona Buchera to właśnie samotranscendencja jest

\footnotetext{
Z. Bauman, Prawodawcy i tłumacze, Warszawa 1998, s. 164. Oblicza doświadczenia aksjologicznego. Studia i rozprawy..., dz. cyt.

40 A. Siemianowski, Wartości i sens życia z punktu widzenia ontologicznego, w: Wartości dla..., dz. cyt.
} 
„sercem duchowości”41. Przy czym owo samoprzekraczanie rozumiane jest jako „wykraczanie poza własne «ja», oddanie się wyższej sile”42 - szeroko pojmowanej i nieredukowalnej wyłącznie do Boga. Jednym z najistotniejszych aspektów samorozwoju i przemiany człowieka jest poznanie siebie samego. Takie samopoznanie odbywa się poprzez proces doświadczania wartości - ich odkrywania, odczytywania, urzeczywistniania. Duchowość pojmuję jako sferę, w której człowiek zadaje sobie pytania o to, kim jest i jaki jest cel jego działań. Rozwój duchowy natomiast realizowany jest poprzez doświadczanie wartości, refleksję, zadawanie pytań o kwestie fundamentalne i poszukiwanie na nie odpowiedzi. Proces taki prowadzi do zajęcia dojrzałej postawy wobec świata i drugiego człowieka. Niezwykle ciekawym jest stanowisko profesor Krystyny Ostrowskiej, która pojęcie duchowości definiuje, wskazując na zdolność człowieka dojrzałego duchowo do aktów miłości - pojmowanej jednak nie jako emocja, ale jako postawa będąca wynikiem dokonania w pełni świadomego wyboru troski wobec innych przy wykraczaniu poza własne dobro i interes ${ }^{43}$.

Zajęcia uwzględnione w programie kształcenia na kierunku praca socjalna przybierać powinny formę umożliwiającą w pierwszej kolejności (samo)rozwój ich uczestników - także w wymiarze duchowym - pojmowany jako wzrost (samo)świadomości. Po wtóre stać się mają przestrzenią rzeczywistego spotkania i otwartego dialogu. Wspólnym mianownikiem wszelkiej działalności formacyjnej - a za taką uważam pracę ze studentami - jest wychowanie moralne. Kryje się bowiem pod nim wspomniana już pomoc w rozwoju. Wspomnieć należy, że dokonuje się on w sferze poznawczej (w uświadomieniu sobie tego, co jest dobre, a co złe), emocjonalnej (w rozwijaniu wrażliwości moralnej), behawioralnej (w konkretnym postępowaniu moralnym) ${ }^{44}$. Kontakt wzajemny studentów i ich relacja z prowadzącym zajęcia, służyć ma podjęciu trudu świadomego poszukiwania celu i sensu oraz konstruowaniu własnego systemu wartości. A wszystko to dokonać się powinno na bazie wspólnego doświadczania. Istotnym dla kreowania procesu kształcenia jest założenie, że „jako coś obiektywnego doświadczamy wartości takich, które nas szczególnie poruszają i jednocześnie zobowiązują, abyśmy do ich własnego sensu dostosowywali nie tylko treści naszych przeżyć, lecz również zachowañ" ${ }^{45}$. W tego rodzaju przeżyciach człowiek zyskuje mocną świadomość, że niepodjęcie takich aktywności

41 A. Bucher, Psychologie der Spiritualität, Weinheim 2014, s. 45.

42 A. Bucher, Psychologie der..., dz. cyt., s. 30.

$43 \quad$ K. Ostrowska, Wokół rozwoju osobowości i systemu wartości, Warszawa 1998.

$44 \quad$ Zob.: M. Łobocki, Wychowanie moralne w zarysie, Kraków 2002; Z. Marek, Podstawy wychowania moralnego, Kraków 2005.

${ }_{45}$ A. Siemianowski, Wartości i sens życia z punktu widzenia ontologicznego, w: Wartości dla..., dz. cyt. 
oznaczałoby uczynienie rzeczy niewłaściwej. Istotą jest uświadomienie sobie i studentom, że istnieją pewne zasadnicze pytania, które należy sobie postawić.

Dostrzec można jednak pewną istotną trudność w realizacji wyżej nakreślonego planu. Pojawia się bowiem pytanie: jak nie narzucać jedynej określonej odpowiedzi na wspomniane fundamentalne pytania? Zaryzykuję twierdzenie, że właśnie doświadczenie duchowe jest drogą do osiągnięcia celu. Refleksyjny i wrażliwy na potrzeby edukacyjne osób dorosłych organizator szkolnictwa wyższego skonfrontować się musi z kilkoma zasadniczymi pytaniami: Kim jest student - osoba dorosła kontynuująca proces edukacji i ukierunkowana na zdobycie wykształcenia i (samo)rozwój? Na czym polega specyfika wiedzy przekazywanej osobom studiującym - jaki jest jej zakres i charakter? Na czym polega rola nauczyciela akademickiego? Pochylmy się na moment nad ostatnim z przywołanych pytań. W świetle założeń personalizmu jako fundamentu realizacji procesu edukacji na poziomie wyższym wydaje się ono bowiem szczególnie istotne. Malcolm S. Knowles wymienia szereg funkcji, jakie musi przyjąć na siebie nauczyciel akademicki, by należycie wypełniać swe zadania. Są to mianowicie funkcje: diagnostyczna (pomoc w zdefiniowaniu swoich potrzeb), planistyczna (doradzenie przy planowaniu procesu edukacyjnego), motywująca (tworzenie warunków stymulujących zaangażowanie), metodyczna (pomoc w doborze metod i technik uczenia się), udostępniania (materiałów dydaktycznych), ewaluatywna (pomoc w ocenie wyników nauczania) ${ }^{46}$. Zarysowane w niniejszym tekście realia współczesności wymagają od nauczycieli akademickich przyjęcia postawy krytycznej i refleksyjnej.

Europejskie i Krajowe Ramy Kwalifikacji ${ }^{47}$ przywołują kształtowanie postaw jako jedną z głównych kategorii efektów, jakie osiągać powinny poprzez swe działania szkoły wyższe. Kształtowaniu postaw odpowiedzialności i samodzielności, postaw twórczych i kreatywnych opartych na wolności i samodzielności

46 M. S. Knowles, The Growth and Development of Adult Education, w: J. M. Peters and Associates, Building an Effective adult Education Enterprise, San Francisco 1980, s. 21-22.

47 Efekty określone w Europejskich i Krajowych Ramach Kształcenia w zakresie kompetencji: I stopień: zarządzanie złożonymi technicznymi lub zawodowymi działaniami lub projektami, ponoszenie odpowiedzialności za podejmowane decyzje $\mathrm{w}$ nieprzewidywalnych kontekstach związanych z pracą lub nauką, ponoszenie odpowiedzialności za zarządzanie rozwojem zawodowym jednostek i grup; II stopień: zarządzanie i przekształcanie kontekstów związanych z pracą lub nauką, które są złożone, nieprzewidywalne i wymagają nowych podejść strategicznych. Ponoszenie odpowiedzialności za przyczynianie się do rozwoju wiedzy i praktyki zawodowej lub za dokonywanie przeglądów strategicznych wyników zespołów; III stopień: wykazywanie się znaczącym autorytetem, innowacyjnością, autonomią, etyką naukową i zawodową oraz trwałym zaangażowaniem w rozwój nowych idei i procesów w najważniejszych kontekstach pracy zawodowej lub nauki, w tym badań, www.nauka. gov.pl/krajowe-ramy-kwalifikacji (30.01.2017). 
działania, sprzyjają niewątpliwie metody samodzielnego dochodzenia do wiedzy oraz metody praktyczne. To na nich opierać się powinny programy kształcenia studentów kierunków społecznych. Pozwalają bowiem na rzeczywistą konfrontację z realiami przyszłego zawodu i problemami, jakie domagają się rozwiązania. Nie sposób nie odwołać się w tym miejscu do problematyki wartości jako fundamentu kształtowania tożsamości młodych ludzi. Konfrontowanie studentów z wartościami poprzez ich eksponowanie i odkrywanie, wywoływanie w nich emocjonalnych przeżyć, stwarzanie przestrzeni do tworzenia wartości, wyrażania ich w sposób twórczy i mówienia o nich - zastosowanie takich środków służy w moim rozumieniu kształtowaniu postaw i przekonań studentów. Istotnym jest jednak, że proces ten zakładać musi dużą dozę samodzielności oraz refleksyjność i umiejętność krytycznego myślenia - przy zachowaniu przestrzeni wolności.

\section{Bibliografia}

Adamiec M., Doświadczenie przemiany jako kategoria psychologiczna, Katowice 1988.

Bauman Z., Płynna nowoczesność, Kraków 2006.

Bauman Z., Prawodawcy i tłumacze, Warszawa 1998.

Bauman Z., Wieloznaczność nowoczesna. Nowoczesność wieloznaczna, Warszawa 1995.

Bucher A., Psychologie der Spiritualität, Weinheim Basel 2014.

Chudy W., Pedagogia godności. Elementy etyki pedagogicznej, red. A. Szudra, Lublin 2009.

Cohen S., Folk devils and moral panics, London 2011.

Comte-Sponville A., Duchowość ateistyczna, tłum. E. Aduszkiewicz, Warszawa 2011.

Dec I., Personalizm, w: Powszechna Encyklopedia Filozofii, red. A. Maryniarczyk, t. 8, Lublin 2007.

Dec I., Personalizm czy personalizmy?, w: Osoba i realizm w filozofii. Zadania Współczesnej Metafizyki, red. A. Maryniarczyk, K. Stępień, Lublin 2002.

Denek K., Ku uniwersytetowi przyszłości, „Nowa Szkoła” 2010, nr 9 (687).

Frankl V. E., Człowiek w poszukiwaniu sensu, Warszawa 2011.

Frankl V. E., Nieuświadomiony Bóg, Warszawa 1978.

Grabowski M., W stronę antropologii adekwatnej, w: O antropologii Jana Pawła II, red. M. Grabowski, Toruń 2004.

Gorczyca J., Zarys etyki fundamentalnej, Kraków 2014.

Honneth A., Reification: A New Look at an Old Idea, Oxford 2008.

Kelly A. V., Obecne trendy i działania polityczne w szkolnictwie wyższym, tłum. Kwieciński P., „Acta Universitatis Nicolai Copernici. Nauki Humanistyczno-Społeczne. Socjologia wychowania", Toruń 1997, z. XIII (317).

Knowles M.S., The Growth and Development of Adult Education, w: J. M. Peters and Associates, Building an Effective adult Education Enterprise, San Francisco 1980. 
Łobocki M., Wychowanie moralne w zarysie, Kraków 2002.

Marek Z., Podstawy wychowania moralnego, Kraków 2005.

Melosik Z., Uniwersytet i społeczeństwo, Kraków 2009.

Duchliński P., Hołub G. (red.), Oblicza doświadczenia aksjologicznego. Studia i rozprawy, Kraków 2011 (Universum Philosophiae).

Oleszak W., Modele pracy edukacyjnej z ludźmi dorostymi, „General and Professional Education" 2011, nr 1.

Ostrowska K., Wokół rozwoju osobowości i systemu wartości, Warszawa 1998.

Popielski K., Noetyczny wymiar osobowości. Psychologiczna analiza poczucia sensu życia, Lublin 1994.

Radlińska H., Pedagogika społeczna, Wrocław 1961.

Siemianowski A., Wartości i sens życia z punktu widzenia ontologicznego, w: Wartości dla $\dot{z} y c i a$, red. K. Popielski, Lublin 2008.

Sochy P., Duchowy rozwój człowieka. Faza życia, osobowość, wiara, religijność, Kraków 2000.

Skrzypińska K., Granice duchowości-perspektywa pierwsza, „Roczniki Psychologiczne” 15 (2012), nr 1.

Szatur-Jaworska B., Teoretyczne podstawy pracy socjalnej, w: Pedagogika Społeczna, red. T. Pilch, I. Lepalczyk, Kraków 1995.

Szerląg A., Kompetencje absolwentów szkół wyższych na miarę naszych czasów. Wybrane ujęcia, Wrocław 2009.

Sztaba M., Dobro wspólne jako podstawowa wartość społeczna i zasada życia społecznego. Refleksje pedagoga społecznego, w: Centralne kategorie współczesnej i historycznej pedagogiki, red. S. Sztobryn, K. Kamiński, Łódź 2016 (Rzeczywistość edukacyjna, 3).

Thompson K., Moral panic. Key ideas, London 2005.

Węgrzecki A., Wokól filozofii spotkania, Myśl filozoficzna, Kraków 2014.

Wojtyła K., Osoba i czyn oraz inne studia antropologiczne, Lublin 2000.

Wojtyła K., Problem doświadczenia w etyce, „Roczniki Filozoficzne KUL”, nr 2, Lublin 1969. Ustawa o pomocy społecznej z 12 marca 2004 r., Dz. U. z 2004 r. Nr 64, poz. 593).

Ustawa Prawo o szkolnictwie wyższym z dnia 27 lipca 2005 r., Dz. U. z 2005 r. Nr 164, poz. 1365). Brenk M., Praca socjalna w pedagogice społecznej Heleny Radlińskiej, w: Ad novum fructum. Z okazji jubileuszu poznańskich historyków wychowania, red. W. Jamrożek, K. Ratajczak, D. Żołądź-Strzelczyk, www.academia.edu/9099382/Praca_socjalna_w_pedagogice_ spo\%C5\%82ecznej_Heleny_Radli\%C5\%84skiej.

Instytut Rozwoju Służb Społecznych, http://wpis.irss.pl/definicja-pracy-socjalnej. http:// www.nauka.gov.pl/krajowe-ramy-kwalifikacji. 
4/ Uniwersytet Papiesk

Tê. Jana Pawła I 